\title{
Assessment of the Prevalence, Severity, Risk Factors of Anemia Among 2-12 Years of Aged Children Attending a Hospital in Western Uttar Pradesh Region
}

\author{
Sunjay Pathak ${ }^{1}$, Radesh Pathak² \\ ${ }^{1}$ Assistant Professor, General Medicine, Varun Arjun Medical College and Rohelkhand Hospital Banthra, Distt. Shahjahanpur (UP), ${ }^{2}$ Assistant Professor, \\ Department of Paediatric, Varun Arjun Medical College and Rohelkhand Hospital Banthra, Distt Shahjahanpur (UP).
}

\section{Abstract}

Background: This study was done to create awareness among people about the problems of Anemia and health care providers in further management. The aim of this study was to assess the prevalence, severity, risk factors of anemia among 2-12 years of aged children attending a hospital. Subjects and Methods: Blood and stool samples were collected from the patient. Among those children with hemoglobin < $11 \mathrm{~g} / \mathrm{dl}$, were screened for iron deficiency anemia (serum ferritin estimation is done). Among these 500 children, 100 children with a hemoglobin level of $11 \mathrm{gm} / \mathrm{dl}$ and serum ferritin $<12 \mu \mathrm{g} / 1$ were taken up for detailed study. Results: A total of 138 males $62.7 \%$ were having hemoglobin less than $11.4 \mathrm{gm}$. /dl indicating anemia. total 230 female children about $66.5 \%$ were detected with anemia, 73 (31.73\%) children had Hemoglobin levels less than $8 \mathrm{gm}$. /dl indicating severe anemia and about 49 (21.30\%) children had moderate anemia and 31 (13.47\%) had mild anemia and only 77 (33.47\%) were having their hemoglobin concentration of greater than $11.5 \mathrm{gm}$. /dl were classified as non-anemic. Conclusion: Anemia was slightly more prevalent in girls of the same age group as compared to boys.

Keywords: Hemoglobin, Children, Prevalence, Severity.

Corresponding Author: Dr. Radesh Pathak, Assistant Professor, Department of Paediatric, Varun Arjun Medical College and Rohelkhand Hospital Banthra, Distt Shahjahanpur (UP)

Received: December 2019

Accepted: December2019

\section{Introduction}

It is estimated that about 18 to 38 percent of the under 5 years old Iranian children are anemic. ${ }^{[1]}$ In India, 89 million preschool age children suffer from Anemia. ${ }^{[2]}$ As per the World Bank data, the prevalence of anemia among under 5 children, in India is 59 in 2011. ${ }^{[3]}$ According to National Family Health Survey (NFHS-4) data, prevalence among children less than five years of age was reported to be $60 \% \cdot{ }^{[4]}$ Anemia in children is an important health problem in almost all the developing countries of the world with an estimated prevalence of $43 \% \cdot{ }^{[5]}$ The World Health Organization (WHO) has estimated that globally 1.62 billion people are anemic, with the highest prevalence of anemia (47.4\%) among preschool-aged children; of these 293 million children, 89 million live in India. ${ }^{[6]}$ The third National Family Health Survey (NFHS) 2005-2006 revealed that at least $80 \%$ of Indian children aged 12-23 months are anemic. $^{[7]}$

Anemia has a variable impact on physical development and children show poor attentiveness, memory and academic performance. ${ }^{[8]}$ Children who suffer from anemia have delayed psychomotor development and impaired performance; in addition, they experience impaired coordination of language and motor skills, equivalent to a 510-point deficit in intelligence quotient. ${ }^{[9-12]}$ Anemia is associated with socioeconomic, biological, environmental and nutritional factors.

In developing countries, the most common cause of Anemia is nutritional; however, other factors like low birth weight, early cord clamping, maternal anemia, high rates of infectious disease including malaria, Helicobacter pylori, helminth infection, poverty, poor access to iron-rich foods and other nutritional deficiencies plays a role. The early years of life are one of the most critical stages of human development and any physical or psychological damage that causes sustained effects on other stages of human development. ${ }^{[13-17]}$ Iron deficiency anemia continues to be an overwhelmingly major cause of anemia in the early childhood and a major global health challenge. ${ }^{[18,19]}$ Anemia in children has significant impact. Longitudinal studies consistently indicate that children who were anemic in infancy continue to have poorer cognition, school achievement and more behavior problems into middle childhood. ${ }^{20}$ As far as we know, there had been no such study on prevalence of anemia in western Uttar Pradesh zone of India, so this study was done to know the burden of disease in these areas which will help us to create awareness among people about the problems of Anemia and health care 
providers in further management.

\section{Subjects and Methods}

This study was conducted in the pediatrics outpatient department (OPD) of a teaching hospital located in Banthra, district Shahjanpur, Uttar Pradesh a period of 6 months. The children (2-12 years age group), and their parents, who attended the OPD, were informed about the purpose and the method of the research and the voluntary nature of participation in the study verbally and in written form.

\section{Inclusion Criteria}

- Children in the age group of 2 Years to 12years;

- Those children with hemoglobin level less than 11 $\mathrm{gm} / \mathrm{dl}$;

- Those children with serum ferritin level less than $12 \mu \mathrm{g} / \mathrm{L}$

\section{Exclusion Criteria}

- Children with hemolytic anemia and bleeding diathesis

- Children with chronic disease

- Children with anemia secondary to leukemia, aplastic anemia.

On admission, a detailed history of the patient was recorded; a thorough physical examination was carried out and below mentioned investigations was done and recorded on a proforma. Blood and stool samples were collected from the patient. Among those children with hemoglobin $<11 \mathrm{~g} / \mathrm{dl}$, were screened for iron deficiency anemia (serum ferritin estimation is done).Amongthese 450 children, 100 children with a hemoglobin level of $11 \mathrm{gm} / \mathrm{dl}$ and serum ferritin <12 $\mu \mathrm{g} / \mathrm{l}$ were taken up for detailed study.

Following haematological investigations done in enrolled patients: hemoglobin and haematocrit estimation, white blood cell count: total and differential, total red blood cell count, reticulocyte count, mean corpuscular volume, mean corpuscular hemoglobin concentration, red cell distribution width, erythrocyte sedimentation rate, peripheral blood smear examination, serum iron, serum ferritin, transferrin saturation and TIBC. The WHO criterion (hemoglobin $<11$ $\mathrm{g} / \mathrm{dL}$ ) was used to diagnose anemia. To categorize the degree of anemia, the following cut-off points were used: 10.0-10.9 g/dL, mild anemia: 7.0-9.9g/dL, moderate anemia: $<7 \mathrm{~g} / \mathrm{dL}$, severe anemia.

\section{Sample Size}

A total of 450 children of either sex were included. A $2 \mathrm{ml}$ non- fasting blood sample was collected from each child from the antecubital vein into a heparinized Vacutainer by a trained phlebotomist. The sample was analyzed within 4 hours of blood sampling.

\section{Statistical Analysis}

Data were entered into a Microsoft excel spread sheet and then analyzed by SPSS 20.0.1 and graph pad prism version 5 . Data have been summarized as mean and standard deviation for numerical variables and count and percentages for categorical variables. Chi-square test or Fischer's exact test, Z-test (standard normal deviate) was used to test the significant difference between two proportions.

Results

220 of the children $(48.88 \%)$ were male and $230(51.11 \%)$ were female Figure 1. A higher proportion $(48.87 \%)$ of children was in the age group of 2-6 years. The children were distributed into various age groups as depicted in Figure 2. Atotalof146(32.44\%)children were anemic and mild, moderate, and severe Anemia was found in $56.16 \%, 41.78 \%$, and $2.05 \%$, respectively Figure 3. educational status of parents were shown in Figure 4.

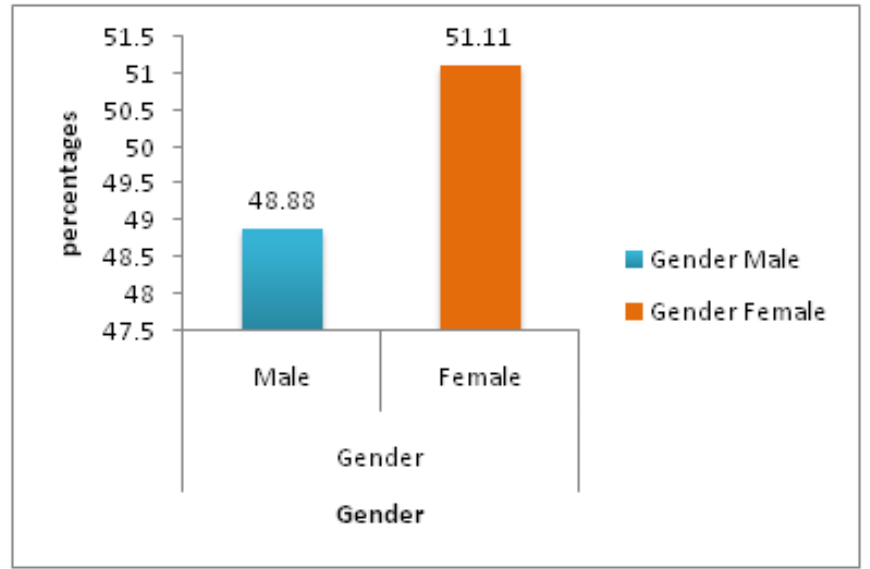

Figure 1: Gender wise distribution of total study group

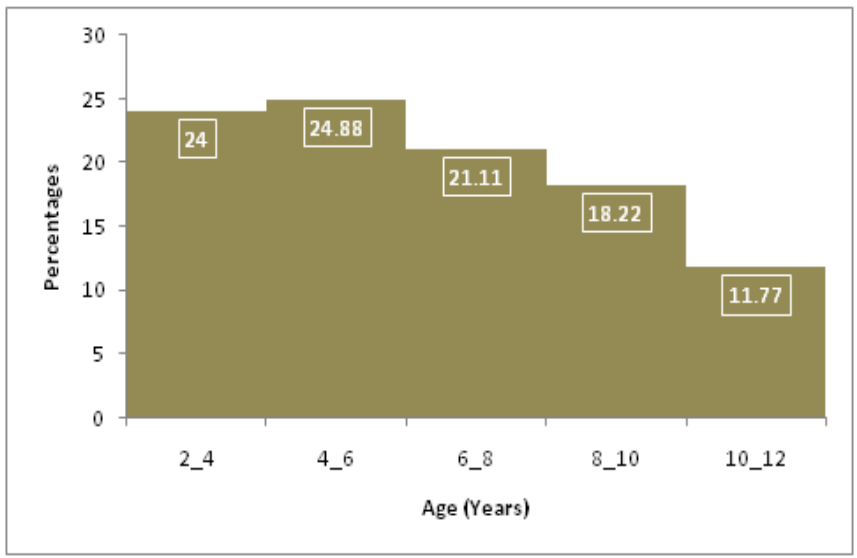

Figure 2: Age wise distribution

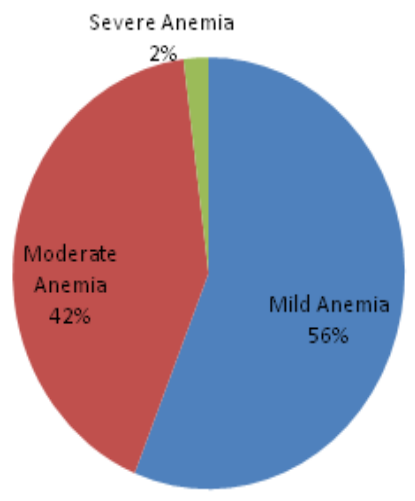

Figure 3: degree of Anemia 


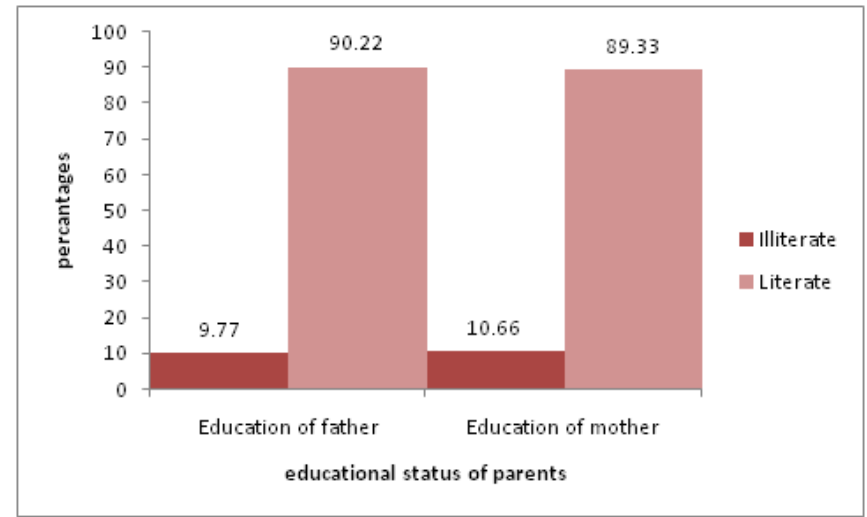

Figure 4: Educational status of parents

The degree of Anemia based on sex distribution showed that both mild and moderate Anemia was more prevalent in girls (19.38\% and $14.54 \%)$ compared to boys $(17.05 \%$ and 12.44\%) (Table No.1).

Table 1: Frequency of Anemia in participants in the study by gender

\begin{tabular}{|l|l|l|l|l|l|}
\hline \multirow{3}{*}{ Gender } & \multicolumn{4}{|c|}{ Anemia } & \multirow{2}{*}{ Total } \\
\cline { 2 - 6 } & Absent & Mild & Moderate & Severe & \\
\cline { 2 - 6 } & $\begin{array}{l}\text { Number } \\
(\%)\end{array}$ & $\begin{array}{l}\text { Number } \\
(\%)\end{array}$ & $\begin{array}{l}\text { Number } \\
(\%)\end{array}$ & $\begin{array}{l}\text { Number } \\
(\%)\end{array}$ & $\begin{array}{l}\text { Number } \\
(\%)\end{array}$ \\
\hline Male & 153 & 38 & 28 & 1 & 220 \\
& $(69.54 \%)$ & $(17.27 \%)$ & $(12.72 \%)$ & $(0.45 \%)$ & $(100)$ \\
\hline Female & 150 & 45 & 34 & 1 & 230 \\
& $(65.21 \%)$ & $(19.56 \%)$ & $(14.78 \%)$ & $(0.43 \%)$ & $(100)$ \\
\hline Total & $303(67.33 \%)$ & $\begin{array}{l}83 \\
(18.44 \%)\end{array}$ & $\begin{array}{l}62 \\
(13.77 \%)\end{array}$ & $\begin{array}{l}2 \\
(0.44 \%)\end{array}$ & $\begin{array}{l}450 \\
(100)\end{array}$ \\
\hline
\end{tabular}

Table No. 2 shows age wise distribution of number of male children, hemoglobin levels of $<11.4 \mathrm{gm}$. /dl were classified as anemic those with hemoglobin more than $11.5 \mathrm{gm}$. /dl were classified as non-anemic for children of 10 -12 years age 14. A total of 138 males $62.7 \%$ were having hemoglobin less than $11.4 \mathrm{gm}$. /dl indicating anemia. While 27 (12.2\%) having $\mathrm{Hb}$ levels less than $8 \mathrm{gm} . / \mathrm{dl}$ indicating severe anemia and $42(19.09 \%)$ having Hemoglobin levels ranging from 8$10 \mathrm{gm} / \mathrm{dl}$ indicating moderate anemia and $69(31.36 \%)$ had hemoglobin levels ranging from $10.1-11.4 \mathrm{gm} . / \mathrm{dl}$ indicating mild anemia.

\section{Table 2: Hemoglobin distributions in Male children of various} age groups

\begin{tabular}{|l|l|l|l|l|l|}
\hline $\begin{array}{l}\text { Age } \\
\text { group }\end{array}$ & $\begin{array}{l}\text { No of } \\
\text { children }\end{array}$ & $\begin{array}{l}<\mathbf{8} \\
\text { gm./dl }\end{array}$ & $\begin{array}{l}\mathbf{8 . 1}-\mathbf{1 0 . 0} \\
\text { gm./dl }\end{array}$ & $\begin{array}{l}\mathbf{1 0 . 1}-\mathbf{1 1 . 4} \\
\text { gm./dl }\end{array}$ & $\begin{array}{l}>\mathbf{1 1 . 5} \\
\text { gm./dl }\end{array}$ \\
\hline $2-4$ & 24 & 6 & 6 & 3 & 9 \\
\hline $4-6$ & 34 & 2 & 7 & 8 & 17 \\
\hline $6-8$ & 62 & 4 & 14 & 31 & 13 \\
\hline $8-10$ & 76 & 7 & 11 & 21 & 37 \\
\hline $10-12$ & 24 & 8 & 4 & 6 & 6 \\
\hline Total & 220 & 27 & 42 & 69 & 82 \\
\hline
\end{tabular}

Table No. 3 shows the female children of various age groups with hemoglobin concentration of the total 230 children about $66.5 \%$ were detected with anemia, 73 (31.73\%) children had Hemoglobin levels less than $8 \mathrm{gm}$. /dl indicating severe anemia and about $49(21.30 \%)$ children had moderate anemia and $31(13.47 \%)$ had mild anemia and only 77 $(33.47 \%)$ were having their hemoglobin concentration of greater than $11.5 \mathrm{gm}$. /dl were classified as non-anemic.

Table 3: Hemoglobin distributions in female children of various age groups

\begin{tabular}{|l|l|l|l|l|l|}
\hline $\begin{array}{l}\text { Age } \\
\text { group }\end{array}$ & $\begin{array}{l}\text { No of } \\
\text { children }\end{array}$ & $\begin{array}{l}<\mathbf{8} \\
\text { gm./dl }\end{array}$ & $\begin{array}{l}\mathbf{8 . 1}-\mathbf{1 0 . 0} \\
\text { gm./dl }\end{array}$ & $\begin{array}{l}\mathbf{1 0 . 1}-\mathbf{1 1 . 4} \\
\text { gm./dl }\end{array}$ & $\begin{array}{l}>\mathbf{1 1 . 5} \\
\text { gm./dl }\end{array}$ \\
\hline $2-4$ & 23 & 6 & 5 & 5 & 7 \\
\hline $4-6$ & 46 & 19 & 9 & 3 & 15 \\
\hline $6-8$ & 43 & 12 & 8 & 5 & 18 \\
\hline $8-10$ & 83 & 24 & 17 & 12 & 30 \\
\hline $10-12$ & 35 & 12 & 10 & 6 & 7 \\
\hline Total & 230 & 73 & 49 & 31 & 77 \\
\hline
\end{tabular}

\section{Discussion}

Iron Deficiency Anemia affects $43 \%$ of preschool children all over the world especially in developing countries, in which the present prevalence rates of four times higher than those found in industrialized countries, this high prevalence is associated with poor sanitary conditions and low socio economic status and high morbidity among infants. ${ }^{[21]}$ In our study we found an overall prevalence of IDA in our population was $61 \%$. There was slight difference in prevalence of IDA among males and females while in former the percentage was 58.9 in latter it was $63.2 \%$ and also the number of individuals suffering from severe anemia was different in males about $8.6 \%$ individuals had severe anemia and in females $32.18 \%$ were severely anemic. This could probably be due to the fact that in our population about $87(n=174) 50.0 \%$ of females were older than 11 years and some of them may have reached menarche.

In a similar study by Verma $\mathrm{M}$ et al; reported the overall prevalence of anemia of $57.5 \%$ with girls having higher prevalence of anemia and more menarchal girls were anemic as compared to those who did not attend menarche. ${ }^{[22]}$ Vasanthi et al. assessed the iron nutritional status among 312 rural school girls of Delhi. ${ }^{[23]}$ The prevalence of anemia $(\mathrm{Hb}<12 \mathrm{~g} / \mathrm{dl})$ was $28 \%$ in girls who had attained menarche and 22\% in girls who had not attained menarche. In another study by Sheshadri S among 1, 500 rural girls (10-19 yrs.) from 10 villages in Gujarat, the prevalence of anemia $(\mathrm{Hb}<12 \mathrm{~g} / \mathrm{dl})$ was reported to be $60 \% .{ }^{[24]}$ In another study in Delhi, anemia occurred in $46.6 \%$ of high socio- economic and $56 \%$ of lower middle socioeconomic class girls. ${ }^{[25]}$ In a similar study by Toteja et al in adolescent females in 16 districts of 11 states across India found higher prevalence of anemia of $90.1 \%$.

The most prevalent conditions were moderate and mild Anemia, probably because mild and moderate Anemia is usually asymptomatic, and may remain undetected and untreated. $^{[26,27]}$ This study showed a higher prevalence (43.9\%) of Anemia, in the 2-4 years age group followed by $30.9 \%$ in the 4-6 years age group. A significantly higher prevalence of Anemia in the 1-3 years age group compared to 3-5 years age group was also reported in a study done on rural preschool children in Maharashtra. ${ }^{[28]}$ The prevalence of Anemia in males in this study was $30 \%$ and slightly higher $34.4 \%$ in females. A similar higher prevalence $(54.4 \%)$ of Anemia in girls has been reported in a study done on adolescent school children in urban Kathmandu, Nepal. ${ }^{[29]}$ In a study on prevalence of Anemia in school children of Kattankulathur, Tamil Nadu, a higher prevalence of Anemia was found in girls. ${ }^{[30]}$ Basu et al. also found a high prevalence 
of Anemia among girls in Chandigarh. ${ }^{[31]}$

\section{Conclusion}

IDA was slightly more prevalent in girls of the same age group as compared to boys. Lower socioeconomic status was linked with decreased Hemoglobin levels probably due to nutritional deficiencies. The Government of India launched the National Program of Nutritional Support to Primary Education NSPE. Though the primary objective of this program was to improve school attendance, it is likely to have a major impact on nutritional status of school children. It should be investigated further and appropriate health care delivery steps should be initiated which might help in the improvement of cognition and learning process in children.

\section{References}

1. Ghasemi A, Keikhaei B. Effects of Nutritional variables in children with iron deficiency anemia. International Journal of Pediatrics, 2014; 2(3.1): 183-87. doi: 10.22038/ijp.2014.2619

2. McLean E, Cogswell M, Egli I, Wojdyla D, and de Benoist B. Worldwide prevalence of Anemia, WHO Vitamin and Mineral Nutrition Information System, 1993- 2005. Public Health Nutr. 2009;12(4):444-54.

3. Stevens GA, Finucane MM, De-Regil LM, Paciorek CJ, Flaxman SR, Branca F, et al. Global, regional, and national trends in hemoglobin concentration and prevalence of total and severe anemia in children and pregnant and non-pregnant women for 1995-2011: a systematic analysis of population- representative data. Lancet Glob Health. 2013; $1(1): \mathrm{e} 16-25$.

4. Key Findings from NFHS. [Last accessed on 2016 Feb 23]. Availableat: http://www.rchiips.org/NFHS/factsheet_NFHS -4.shtml.

5. Demaeyer EM. Preventing and controlling iron deficiency anemia through primary health care. World Health Organization, Geneva.1989.

6. Benoist B, McLean E, Egli I, Cogswell. Worldwide Prevalence of Anemia 1993-2005. eds. Geneva, Switzerland: World Health Organization; 2008.

7. International Institute for Population Sciences and Macro International. National Family Health Survey (NFHS-3), 2005-2006: Key Findings. Mumbai, India: International Institute for Population Sciences; 2007.

8. Lozoff B, Jemenez E, Wolf AW. Long term developmental outcome of infants with iron deficiency. New Eng J Med.1991; 325:687-94.

9. Politt E. Iron deficiency and cognitive function. Annu Rev Nutr. 1993; 13:521-37.

10. Halterman JS, Kaczorowski JM, Aligne CA, Auinger P, Szilagyi PG. Iron deficiency and cognitive achievement among school-aged children and adolescents in the United States. Pediatr. 2001; 107:13816.

11. Walter T, Kovalskys J, Stekel A. Effect of mild iron deficiency on infant mental development scores. J Pediatr.1983; 102:519-22.

12. Lozoff B, Smith J, Liberzon T, Argul-Barroso R, Jiminez E.
Longitudinal analysis of cognitive and motor effects of iron deficiency in infancy. Pediatr Res. 2004;55:23A.

13. Schauer C, Zlotkin S. Home fortification with micronutrient sprinkles - A new approach for the prevention and treatment of nutritional anemias. Paediatr Child Health. 2003; 8(2):87-90.

14. KhosraviAnbaran Z, BaghdariN, SadeghiSahebzad E, Moradi M, Karimi FZ. Comparing Infant Nutrition in Wanted and Unwanted Pregnancies. Int J Pediatr 2016; 4(12): 4043-50.

15. Khadivzadeh T, Karimi FZ, Tara F, Bagheri S. The Effect of Postpartum Mother- Infant Skin-to-Skin Contact on Exclusive Breastfeeding In neonatal period: A Randomized Controlled Trial. Int J Pediatr 2016; 4(5):5409-17.

16. Karimi A, Bagheri S, Khadivzadeh T, MirzaiiNajmabadiKh. The Effect of an Interventional Program, Based on the Theory of Ethology, on Breastfeeding Competence of Infants. Iranian Journal of Neonatology 2014; 5(3): 10-12.

17. Anbaran ZK, Baghdari N, Pourshirazi M, Karimi FZ, Rezvanifard M, Mazlom SR. Postpartum sexual function in women and infant feeding methods. J Pak Med Assoc 2015; 65(3):248-252.

18. Pacifici, G. Effects of Iron in Neonates and Young Infants: a Review. International Journal of Pediatrics, 2016; 4(7): 2256-71. doi: 10.22038/ijp.2016.6991.

19. Saeidi M,Vakili R,KhakshourA,TaghizadeMoghaddam H, Kiani MA, Zarif $\mathrm{B}$, et al. Iron and multivitamin supplements in children and its association with growth rate. International Journal of Pediatrics. 2013; 1(1):13-17.

20. WHO. Haemoglobin concentrations for the diagnosis of Anemia and assessment of severity. Vitamin and Mineral Nutrition Information System. Geneva, World Health Organization,2011.

21. Finch CA. Iron nutrition, Food and Nutrition in health and disease. Ann NY AcadSci 1977; 300; 22.

22. Verma M,Chhatwal J. Prevalence of anemia among urban school children of Punjab. Indian Pediatr 35(12):1181-6 Dec1998.

23. Vasanthi $G$, Pawashe $A B, H$ Susie, $T$ Sujatha, Raman L. Iron nutritional status of adolescent girls from rural area and urban slum. Indian Pediatr 1994; 31:127-132.

24. Sheshadri S. Nutritional Anemia in South Asia. In: Malnutrition in South Asia: A Regional Profile Ed. Gillespie S. Katmandu, UNICEF Regional Office for South Asia 1997; pp75-124.

25. Kapoor G, Aneja S. Nutritional disorders in adolescent girls. Indian Pediatr 1992; 29:969-973.

26. Maharashtra, India. Indian Journal of Community Health 2012; 24:4-8.

27. Tiwari K. Seshadri S. The prevalence of anemia and morbidity profile among school going adolescent girls of urban Kathmandu, Nepal. J Nep Med Assoc 2000; 39:319-25.

28. Basu S, ,Basu S, Hazarika R, Parmar V. Prevalence of anemia among school going adolescents of Chandigarh. Indian Pediatr. 2005; 42(6):593-7.

29. Schellenberg D, Schellenberg JR, Mushi A, SavignyDd, Mgalula L, Mbuya C, et al. The silent burden of Anemia in Tanzanian children: a community-based study. Bull World Health Organ. 2003; 81(8):58190. Epub 2003 Oct14.

30. Crawley J. Reducing the burden of Anemia in infants and young children in malaria- endemic countries of Africa: From evidence to action. Am J Trop Med Hyg. 2004; 71(2 Suppl): 25-34.

31. Arlappa N, Balakrishna N, Laxmaiah A, and Brahmam GNV. Prevalence of Anemia among rural pre-school children.

Copyright: () the author(s), 2019. It is an open-access article distributed under the terms of the Creative Commons Attribution License (CC BY 4.0), which permits authors to retain ownership of the copyright for their content, and allow anyone to download, reuse, reprint, modify, distribute and/or copy the content as long as the original authors and source are cited.

How to cite this article: Pathak S, Pathak R. Assessment of the Prevalence, Severity, Risk Factors of Anemia Among 2-12 Years of Aged Children Attending a Hospital in Western Uttar Pradesh Region. Acad. J Med. 2019;2(2):125-28.

DOI: dx.doi.org/10.21276/ajm.2019.2.2.31

Source of Support: Nil, Conflict of Interest: None declared. 